\title{
Properties of proteins binding plasma progesterone in pregnant Cape porcupines (Hystrix africaeaustralis)
}

\author{
A. I. Louw ${ }^{1}$, V. van $\mathrm{Wyk}^{2}$ and R. J. van Aarde ${ }^{2 *}$ \\ 'Department of Biochemistry, University of Pretoria, Pretoria 0002, South Africa; and \\ ${ }^{2}$ Department of Zoology, Mammal Research Institute, University of Pretoria, Pretoria 0002, \\ South Africa
}

\begin{abstract}
Summary. The properties of progesterone-binding proteins in plasma of pregnant Cape porcupines were investigated using radiolabelled progesterone and either progesterone or cortisol as competing ligands as well as native plasma and heated $\left(60^{\circ} \mathrm{C}\right.$ for $\left.30 \mathrm{~min}\right)$ plasma.

The results demonstrated that plasma from pregnant porcupines contains corticosteroid-binding globulin, but that it constitutes a significant portion of plasma progesterone-binding proteins only during the early stages of pregnancy. Corticosteroidbinding globulin of porcupines appears to be as heat labile as that of guinea-pigs. Concentrations of progesterone-binding proteins in plasma increased during pregnancy to reach concentrations at the eleventh week that were 25 times higher than those of progesterone; concentrations increased significantly $\left(r^{2}=0.88\right)$ with the increase in progesterone concentration.

The results indicate that plasma progesterone-binding proteins in Cape porcupines (Old World hystricomorph) are similar in composition to those in guinea-pigs (New World hystricomorph).
\end{abstract}

Key'words: Cape porcupine; plasma-progesterone-binding proteins

\section{Introduction}

Gestation in Cape porcupines (Old World hysticomorph rodent) lasts $93-94$ days and is characterized by the presence of accessory corpora lutea and a marked increase in circulating concentrations of total progesterone 25-30 days after fertilization (van Aarde \& Potgieter, 1986). Peak concentrations of progesterone are similar to those in pregnant New World hystricomorph rodents, such as guinea-pigs (Cavia porcellus), casiragua (Proechimys quairae) and cuis (Galea musteloides) (Illingworth et al., 1973; Heap \& Illingworth, 1974; Heap et al., 1981), but higher than those of most other mammals (Tam, 1974). This may be due to the presence of plasma progesterone-binding proteins (PPBP) such as progesterone-binding globulin (PBG) and corticosteroid-binding globulin (CBG) (Illingworth et al., 1973; Heap \& Illingworth, 1974; Heap et al., 1981; van Aarde \& Potgieter, 1986) which are presumed to slow the metabolic clearance of progesterone from the circulation during pregnancy (Illingworth et al.; Heap \& Illingworth, 1974).

Concentrations of plasma progesterone-binding proteins are high during late pregnancy in guinea-pigs and have been shown to have high association $\left(K_{\mathrm{a}}\right)$ and dissociation $\left(K_{\mathrm{d}}\right)$ constants for progesterone (Stroupe \& Westphal, 1975). In porcupines, PPBPs have a high affinity $\left(K_{\mathrm{a}}=0.8 \times 10^{9} \mathrm{~mol}^{-1} \mathrm{l}\right)$ for progesterone, and increase in concentration during pregnancy (van Aarde \& Potgieter, 1986), but these concentrations are considerably lower than those recorded for pregnant guinea-pigs, casiragua, cuis, degu (Octodon degus), and viscacha (Lagostomus maximus; 
Heap et al., 1981). Moreover, CBG was not detected in pregnant porcupines (van Aarde \& Potgieter, 1986), even though its presence in plasma is usually related to that of oestrogen (Heap \& Illingworth, 1974), which occurs in high concentrations $\left(170-210 \mathrm{pg} \mathrm{ml}^{-1}\right)$ in pregnant porcupines (van Aarde \& Potgieter, 1986). This finding suggests a significant difference between pregnant Cape porcupines and guinea-pigs; plasma of the latter has not only a sixth of the concentration of oestradiol of the porcupine, but also contains CBG which increases in concentration during pregnancy (Heap \& Illingworth, 1974). The studies on Cape porcupines, however, were conducted with the synthetic progestin, promegestone, which has a low affinity for plasma proteins and may not even recognize CBG (see Milgrom et al., 1973a; Philibert \& Raynaud, 1974; Philibert et al., 1977; Siiteri, et al., 1982).

The binding properties of PPBP in pregnant Cape porcupine were reinvestigated, using radiolabelled progesterone as ligand and an equilibrium dialysis method that uses an inexpensive and simple system constructed from Eppendorf tubes (Reinard \& Jacobsen, 1989). Results were obtained for native and heat-treated plasma, using either unlabelled progesterone or cortisol as competing ligand to examine plasma from the pregnant females for the presence of $\mathrm{CBG}$. Temporal changes in PPBP and progesterone concentrations during pregnancy were also investigated.

\section{Materials and Methods}

\section{Collection of plasma}

Plasma $(100 \mathrm{ml})$ was collected from three pregnant porcupines, killed on day 35,68 or 87 of pregnancy and stored in $10 \mathrm{ml}$ aliquots at $-20^{\circ} \mathrm{C}$ until assayed. Gestational age was determined using a modification of the equation of Huggett \& Widdas (1951) according to van Aarde (1987). After thawing, the plasma was centrifuged (1500 $\mathrm{g}$ for $5 \mathrm{~min}$ at $4^{\circ} \mathrm{C}$ ) and the precipitate discarded. Plasma was also collected at weekly intervals from 11 pregnant females to determine temporal changes in concentrations of progesterone and PPBP throughout pregnancy. Samples were pooled for each of the 13 weeks of pregnancy before being analysed.

\section{Determination of protein concentration}

Protein concentrations were determined by ultraviolet absorbance at $280 \mathrm{~nm}$ using a Hitachi U-2000 spectrophotometer (Tokyo, Japan) and a molar extinction coefficient of $\mathrm{E}_{\mathrm{l \textrm {mm }} \mathrm{ml}}^{\mathrm{k \textrm {cm }}},=1$ (see Milgrom et al., 1973b).

\section{Determination of progesterone-binding activity}

The method used was that of Reinard \& Jacobsen (1989) with minor modifications. [1,2,6,7- $\left.{ }^{3} \mathrm{H}\right]$ Progesterone (Code TRK 413, sp. act. $96 \mathrm{Ci} \mathrm{mmol} \mathrm{')} \mathrm{was} \mathrm{obtained} \mathrm{from} \mathrm{Radiochemical} \mathrm{Centre} \mathrm{(Amersham,} \mathrm{UK)} \mathrm{and} \mathrm{a} \mathrm{final}$ concentration of approximately $15 \mathrm{nmoll}^{\prime}{ }^{\prime}$ was prepared in $0.01 \mathrm{~mol}$ Tris- $0.15 \mathrm{~mol} \mathrm{NaCl1^{-1 }}$ buffer (pH 7.4) (Tris- $\mathrm{NaCl}$ buffer).

Nonspecific binding was determined in the presence of $15 \mu \mathrm{mol}$ unlabelled progesterone $1^{1}\left(\Delta^{4}\right.$-pregnene-3,20dione; Sigma, Dorset, UK). Preliminary experiments indicated that equilibrium was reached within $16 \mathrm{~h}$ and that specific binding was linear up to a protein concentration of $0.1-0.2 \mathrm{mg} \mathrm{ml} 1$ incubation medium. The lower chamber of the Eppendorf microtubes contained $0.25 \mathrm{ml}$ of radiolabelled progesterone with or without unlabelled progesterone, whereas the upper chamber contained $0.25 \mathrm{ml}$ of appropriately diluted plasma. Triplicate samples were incubated for $24 \mathrm{~h}$ at $4^{\circ} \mathrm{C}$.

\section{Binding properties of plasma progesterone-binding proteins}

The association and dissociation constants and the concentration of PPBP were determined by equilibrium dialysis using $\left[1,2,6,7-{ }^{3} \mathrm{H}\right]$ progesterone concentrations ranging from 1.25 to $\left.15 \mathrm{nmol}\right]^{\prime}$ and heated plasma $\left(60^{\circ} \mathrm{C}\right.$ for $30 \mathrm{~min}$ ) of 35 - and 68-day pregnant porcupines. Binding data were analysed according to Scatchard (1949) and lines were fitted to data points by least square linear regression analysis.

\section{Contribution of corticosteroid-binding globulin to progesterone-binding activity of plasma progesterone-binding proteins}

Plasma of porcupines at 35,68 and 87 days of pregnancy were thawed and their pH adjusted to $7 \cdot 4$ with $0 \cdot 1$ mol sodium hydrogen phosphate $1^{-1}$ (Merck, Darmstadt, Germany). Aliquots $(1 \mathrm{ml})$ were pipetted into glass extraction 
tubes and one set was incubated at $4^{\circ} \mathrm{C}$ and another at $60^{\circ} \mathrm{C}$ for $30 \mathrm{~min}$. These were centrifuged $(40000 \mathrm{~g}$ for $30 \mathrm{~min}$ at $4 \mathrm{C}$ ); supernatants were collected, diluted with Tris- $\mathrm{NaCl}$ buffer and binding activities of native and heated plasmas were determined in the presence of increasing concentrations $\left(I \times 10^{12}\right.$ to $I \times 10^{5}$ moll $\left.{ }^{1}\right)$ of either unlabelled progesterone or unlabelled cortisol ( $\Delta^{4}$-pregnene-11 $\beta,-17 \alpha, 21-$ rriol-3,20-dione; Sigma, Dorset, UK). The competitive efficiency of cortisol was compared with that of progesterone using the equation of Milgrom et al. (1970).

\section{Relative molecular mass $\left(M_{\mathrm{r}}\right)$ of plasma progesterone-binding proteins}

Pre-swollen Sephacryl S-200 gel (Pharmacia Fine Chemicals, Uppsala, Sweden) was packed into a column $\left(38 \times 5 \mathrm{~cm}^{2}\right)$ and equilibrated with $0.01 \mathrm{~mol}$ Tris- $0.11 \mathrm{~mol} \mathrm{KCl}^{-1}$ buffer, $\mathrm{pH} 8.6$ (Tris- $\mathrm{KCl}$ buffer). Blue Dextran 2000 (Pharmacia, Uppsala, Sweden) was used to determine the void volume $\left(V_{0}=245 \mathrm{ml}\right)$. The calculated total volume $\left(V_{1}\right)$ of the column was $736 \mathrm{ml}$. The column was calibrated with the following proteins in Tris-KCl buffer: cytochrome $c$ $\left(M_{\mathrm{r}}=12500\right)$, chymotrypsinogen a $\left(M_{\mathrm{r}}=25000\right)$, ovalbumin $\left(M_{\mathrm{r}}=45000\right)$, albumin $\left(M_{\mathrm{r}}=68000\right)$, aldolase $\left(M_{\mathrm{r}}=158000\right)$, catalase $\left(M_{\mathrm{r}}=240000\right)$ and ferritin $\left(M_{\mathrm{r}}=450000\right)$.

Plasma ( $5 \mathrm{ml}$ ) from females at 35,68 or 87 days of pregnancy were applied to the Sephacryl S-200 column at $4^{\circ} \mathrm{C}$ and eluted with Tris-KCl buffer at a flow-rate of $32 \mathrm{ml} \mathrm{h}{ }^{2}$. Fractions $(5 \cdot 3 \mathrm{ml})$ were collected in a LKB 7000 Ultrarac fraction collector (LKB, Sweden). Additionally, plasma $(5 \mathrm{ml}$ ) collected from females at 35 or 87 days of pregnancy was heated $\left(60^{\circ} \mathrm{C}\right.$ for $\left.30 \mathrm{~min}\right)$ and also chromatographed. Eluted proteins were detected by measuring the absorbance of fractions at $280 \mathrm{~nm}$. Binding activities of every fifth fraction were determined as described above.

\section{Changes in concentrations of plasma progesterone-binding proteins and progesterone during pregnancy}

The $\mathrm{pH}$ of pooled plasma, collected throughout pregnancy, was adjusted to 7.4 with 0.1 mol sodium hydrogen phosphate l '. Plasma samples $(1 \mathrm{ml})$ were divided into two aliquots, one set was heated $\left(30 \mathrm{~min}\right.$ at $\left.60^{\circ} \mathrm{C}\right)$ and another kept at $4^{\circ} \mathrm{C}$. After centrifugation $\left(40000 \mathrm{~g}\right.$ for $30 \mathrm{~min}$ at $\left.4^{\circ} \mathrm{C}\right)$ and dilution of plasma with Tris- $\mathrm{NaCl}$ buffer, binding assays were conducted as described above. The amount of $\left[1,2,6,7-{ }^{3} \mathrm{H}\right]$ progesterone specifically bound at saturating concentrations was taken to be equivalent to PPBP concentrations.

Concentrations of progesterone in pooled plasma for the 13 weeks of pregnancy were determined by radioimmunoassay as described by van Aarde \& van Wyk (1991). The inter- and intra-assay coefficients of variation were 3 and $1.4 \%$, respectively. The sensitivity of the assay was $3.18 \pm 0.95 \mathrm{pmol} \mathrm{ml}(n=6)$. Recovery of labelled progesterone averaged $81 \cdot 7 \%$.

\section{Results}

\section{Contribution of corticosteroid-binding globulin to progesterone-binding activity of plasma progesterone-binding proteins}

Specific binding of progesterone at an early stage of pregnancy ( 35 days) decreased fivefold after heat treatment of plasma (Table 1). Binding was not affected by heat treatment of plasma collected at a later stage of pregnancy (68 days), suggesting that a heat-labile, progesterone-binding protein, probably CBG (Heap, 1969; Milgrom et al., 1973b), was present on day 35, but not on day 68 of pregnancy.

Table 1. Heat stability of plasma progesterone-binding proteins of Cape porcupines. The $\mathrm{pH}$ of plasma of two different stages of pregnancy was adjusted with $0 \cdot 1 \mathrm{~mol}$ sodium dihydrogen phosphate $\mathrm{l}^{-1}$ and treated at 4 or $60^{\circ} \mathrm{C}$ for $30 \mathrm{~min}$. Values are the means of triplicate assays \pm one SD of the mean

\begin{tabular}{lccccc}
\hline $\begin{array}{l}\text { Days after } \\
\text { conception }\end{array}$ & $\begin{array}{c}\text { Temperature } \\
\left({ }^{\circ} \mathrm{C}\right)\end{array}$ & $\mathrm{pH}$ & $\begin{array}{c}\text { Specific binding } \\
\text { (pmol ml 'plasma) } \\
(\overline{\mathrm{x}} \pm \mathrm{SD})\end{array}$ & $\begin{array}{c}\text { Protein } \\
\text { concentration } \\
\left(\mathrm{mg} \mathrm{ml}{ }^{\prime}\right)\end{array}$ & $\begin{array}{c}\text { Specific } \\
\text { activity } \\
\left(\mathrm{pmol} \mathrm{mg}^{-1}\right)\end{array}$ \\
\hline 35 & 4 & $7 \cdot 4$ & $345 \pm 7$ & $39 \cdot 62$ & $8 \cdot 7$ \\
& 60 & $7 \cdot 4$ & $64 \pm 8$ & $35 \cdot 74$ & $1 \cdot 8$ \\
68 & 4 & $7 \cdot 4$ & $3625 \pm 41$ & $33 \cdot 26$ & 109 \\
& 60 & $7 \cdot 4$ & $3873 \pm 24$ & $31 \cdot 62$ & 113 \\
\hline
\end{tabular}

Displacement of $\left[1,2,6,7-{ }^{3} \mathrm{H}\right]$ progesterone from PPBP of unheated plasma at 35 days of pregnancy by cortisol, followed a similar trend to the displacement curve obtained with progesterone alone (Fig. 1a). After heat treatment of plasma (Fig. 1b) or at later stages of pregnancy (Fig. 1c and 
d), much higher concentrations of cortisol than progesterone were required to displace specifically bound $\left[1,2,6,7-{ }^{3} \mathrm{H}\right]$ progesterone. These results supported the contention that a heat-labile component of PPBP, probably CBG (Heap, 1969; Milgrom et al., 1973b), contributed significantly to progesterone binding on day 35 of pregnancy but not at later stages of pregnancy.

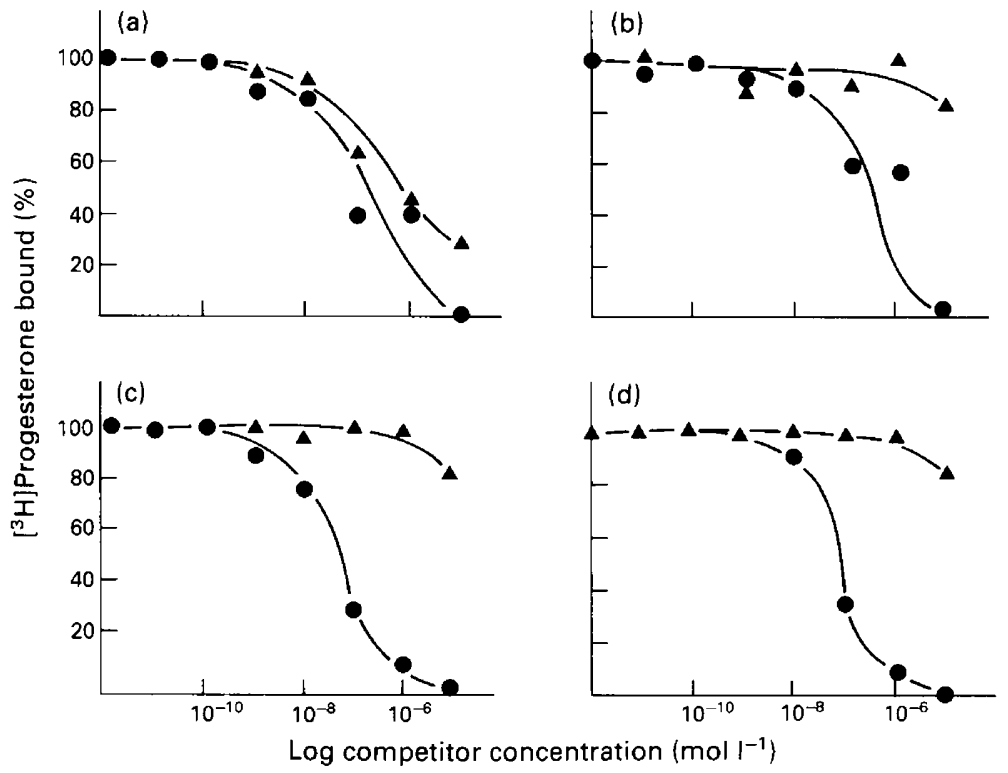

Fig. 1. Displacement of $\left[1,2,6,7-{ }_{-}^{3} \mathrm{H}\right]$ progesterone from plasma progesterone-binding proteins of porcupines by unlabelled progesterone ( $)$ and cortisol $(\boldsymbol{\Delta})$. (a) and (b) day 35 and (c) and (d) day 68 of pregnancy. (a) and (c) unheated plasma; (b) and (d) heated plasma ( $60^{\circ} \mathrm{C}$ for $30 \mathrm{~min}$ ). Protein concentrations were $<0 \cdot 1 \mathrm{mg} \mathrm{ml}^{-1}$.

\section{Relative molecular masses of plasma progesterone-binding proteins}

The peaks for specifically bound progesterone and thus the molecular masses of the binding proteins in unheated plasma are apparently different for the three stages of pregnancy investigated. Elution volumes from the calibrated Sephacryl S-200 column suggest relative molecular masses for PPBP of 130, 213 and 242 for days 35, 68 and 87 of pregnancy, respectively (Fig. 2). After heat treatment of day 35 plasma the molecular mass of the principal binding protein (Fig. 2c) was higher $\left(M_{\mathrm{r}}=195\right)$ and nearer to that of the two binding proteins at later stages of pregnancy (Fig. 2d). The other binding entity had a molecular mass of 104 and probably represented residual CBG not destroyed by heat (Daughaday et al., 1962). Heat treatment of day 87 plasma did not lead to a change in the molecular mass of the binding entity, nor was a separate binding protein detected at a lower molecular mass (results not shown). The latter results signify the absence of significant quantities of the heat-labile component in PPBP at this stage of pregnancy.

\section{Scatchard analysis of plasma progesterone-binding proteins}

The concentration of PPBP ml-1 of heated plasma on day $68\left(2793 \mathrm{pmol} \mathrm{ml}^{-1}\right.$ plasma) was 40 times higher than on day 35 of pregnancy $\left(67.8 \mathrm{pmol} \mathrm{m}^{-1}\right.$ plasma) (Fig. 3a and b), while the $K_{\mathrm{d}}$ values were similar $\left(1.82 \times 10^{-9}\right.$ and $2.1 \times 10^{-9} \mathrm{~mol}^{-1}$, respectively). 


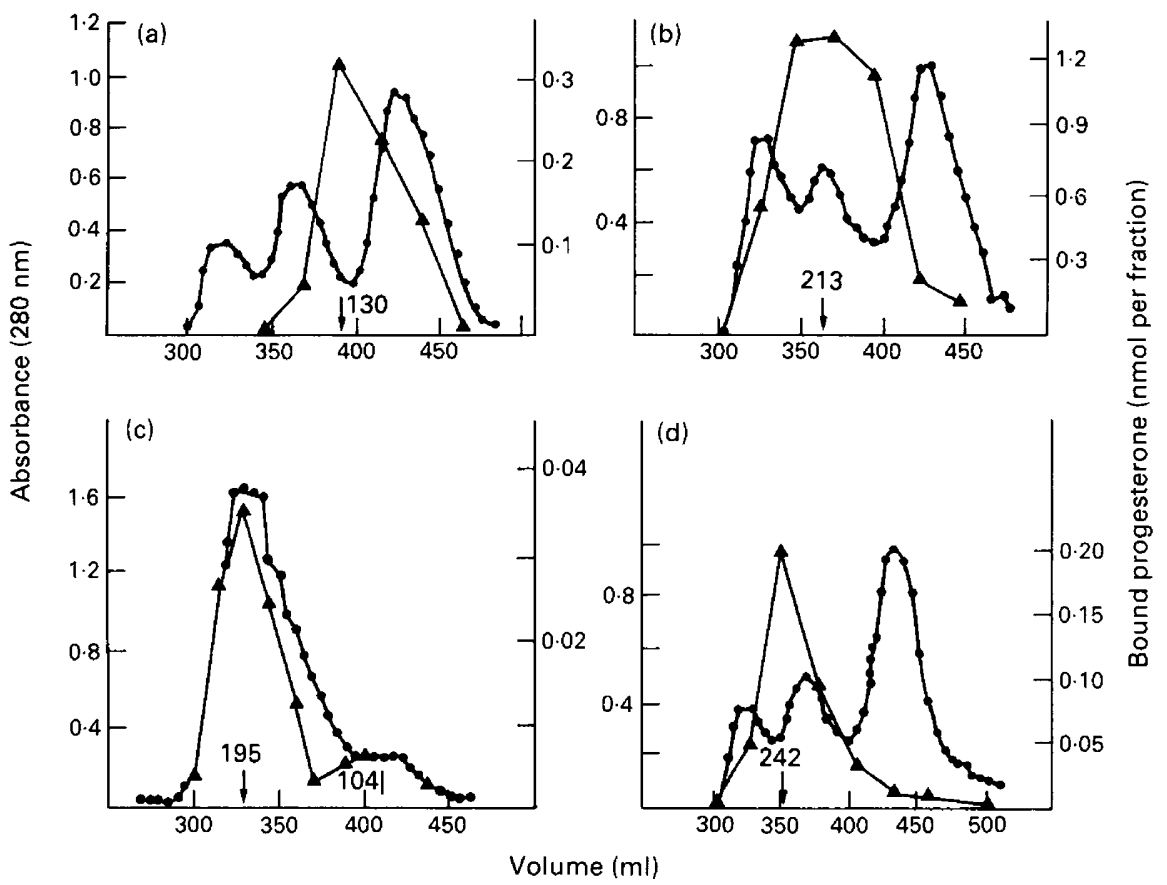

Fig. 2. Specific binding of progesterone (A) and absorbance at $280 \mathrm{~nm}(\boldsymbol{)})$ of fractions collected after Sephacryl S-200 chromatography of porcupine plasma. Specific binding was determined by equilibrium dialysis ( $10 \mu \mathrm{l}$ aliquots were used for binding activity determinations). (a) day 35 , (b) day 68 , (c) day 35 and (d) day 87 of pregnancy. (a), (b) and (d) unheated plasma; (c) heated plasma $\left(60^{\circ} \mathrm{C}\right.$ for $\left.30 \mathrm{~min}\right)$. Proteins were eluted with Tris-KCl buffer $(\mathrm{pH} \mathrm{8.6)}$ at $32 \mathrm{ml} \mathrm{h}^{-1}$ and fractions of $5.3 \mathrm{ml}$ were collected. The $M_{\mathrm{r}}$ of peak fractions are given at the corresponding arrows.

\section{Temporal changes in concentrations of plasma progesterone-binding proteins and progesterone during pregnancy}

The specific binding capacity of PPBP in aliquots of heated plasma of 11 porcupines over 13 weeks of pregnancy (Fig. 4a) shows that total progesterone remained $<0 \cdot 1 \mathrm{nmol} \mathrm{ml}^{-1}$ plasma (Fig. 4b) for the first 5 weeks of pregnancy after which it increased to about $0.5 \mathrm{nmol} \mathrm{ml}^{-1}$ plasma at 11 weeks of pregnancy. Concentrations of PPBP remained low for the first five weeks of pregnancy $<0.007 \mathrm{nmol} \mathrm{ml}^{-1}$ plasma), increasing thereafter to reach a peak value of $13.8 \mathrm{nmol} \mathrm{ml} \mathrm{m}^{-1}$ plasma by the eleventh week of pregnancy. PPBP concentrations increased significantly $\left(r^{2}=0.88\right)$ with the increase in progesterone concentration. The molar ratio of PPBP to progesterone remained low for the first five weeks of pregnancy $(<0.2)$, increasing to a value of 25.7 at week 11 of pregnancy; and decreasing to 16 by week 13 of pregnancy (Fig. 4c).

\section{Discussion}

Heating of plasma collected from female porcupines, 35 and 68 days after fertilization, resulted in an $80 \%$ loss of progesterone-binding activity in the former but not in the latter case. These results suggest that a heat-labile binding entity is present only during the early stages of pregnancy. The affinity of cortisol for PBG (heat stable component of PPBP) of Cape porcupines and guinea-pigs was considerably lower than that of progesterone (Stroupe \& Westphal, 1975; van Wyk, 1991). Affinities of both progesterone and cortisol for CBG of guinea-pigs, on the contrary, were shown to 


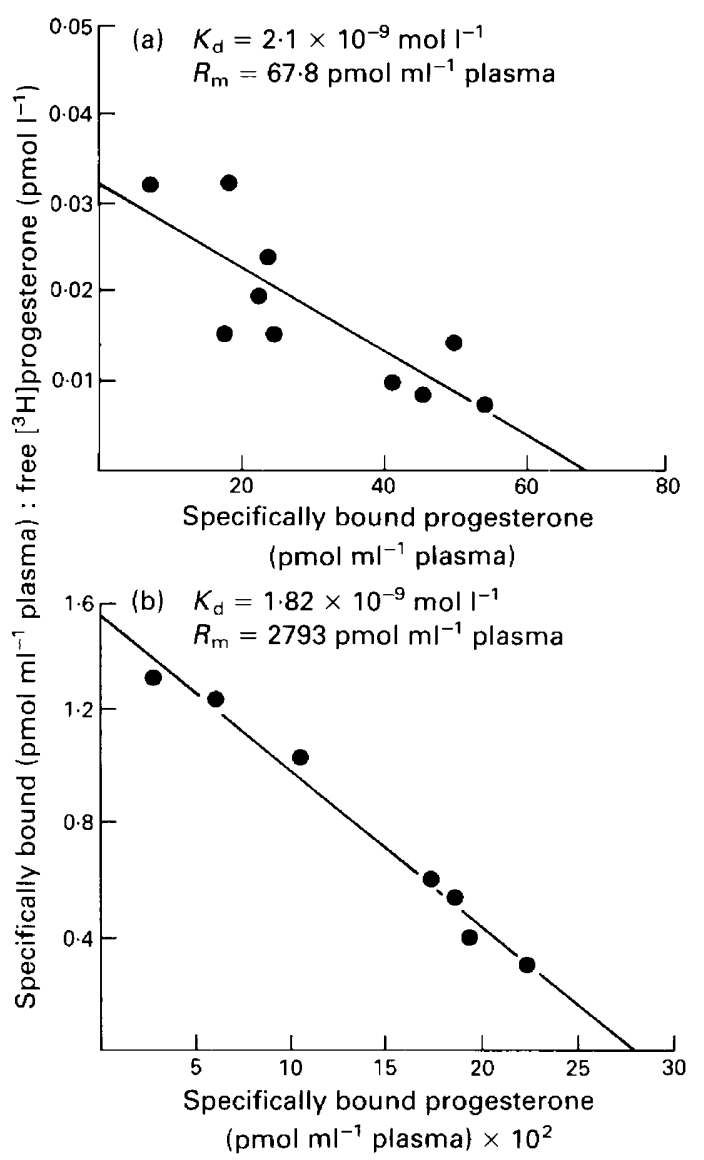

Fig. 3. Scatchard analysis of $\left[1,2,6,7-{ }^{3} \mathrm{H}\right]$ progesterone binding to plasma progesterone-binding proteins in heated plasma of Cape porcupines of (a) day $35(r=0.90)$ and (b) day 68 of pregnancy $(r=0.99)$. Plasma was diluted to 0.48 and $0.01 \mathrm{mg}$ protein $\mathrm{ml}^{-1}$ for (a) and (b), respectively, and $1 \cdot 25-15 \mathrm{nmol}\left[1,2,6,7-{ }^{3} \mathrm{H}\right]$ progesterone $\mathrm{I}^{-1}$ was used for binding activity experiments.

be very similar (Burton et al., 1971). Since specifically bound progesterone was equally displaced from PPBP by cortisol and progesterone in native, but not heated, plasma (Fig. la and b), it can be concluded that the heat-labile binding entity in PPBP is CBG.

Corticosteroid-binding globulin in plasma of porcupines therefore appears to be heat-labile as in guinea-pigs (Heap, 1969; Milgrom et al., 1973b) and apparently is a significant constituent of PPBP only during the early stages of pregnancy (Table 1, Fig. 1). The failure of van Aarde \& Potgieter (1986) to demonstrate the presence of CBG in porcupine plasma was probably due to the stage of pregnancy (not specified) at which the assays were conducted or to the apparent inability of synthetic progestins to recognize CBG or to both factors (Milgrom et al., 1973a; Philibert \& Raynaud, 1974; Philibert et al., 1977; Siiteri et al., 1982).

The presence of a minor binding fraction after heat treatment of plasma (Fig. 2c), suggests that CBG was incompletely denatured and has a lower molecular mass than PPBP. The molecular mass of guinea-pig PBG was shown to be higher than that of albumin or CBG (Burton et al., 1971). The $M_{\mathrm{r}}$ of the major progesterone-binding entity in heated plasma of Cape porcupines was 195-242 (Fig. 2), a value approximately twice that determined for guinea-pig PBG by the same method (Burton et al., 1971). The reason for this difference is unknown but may be due to differences in 

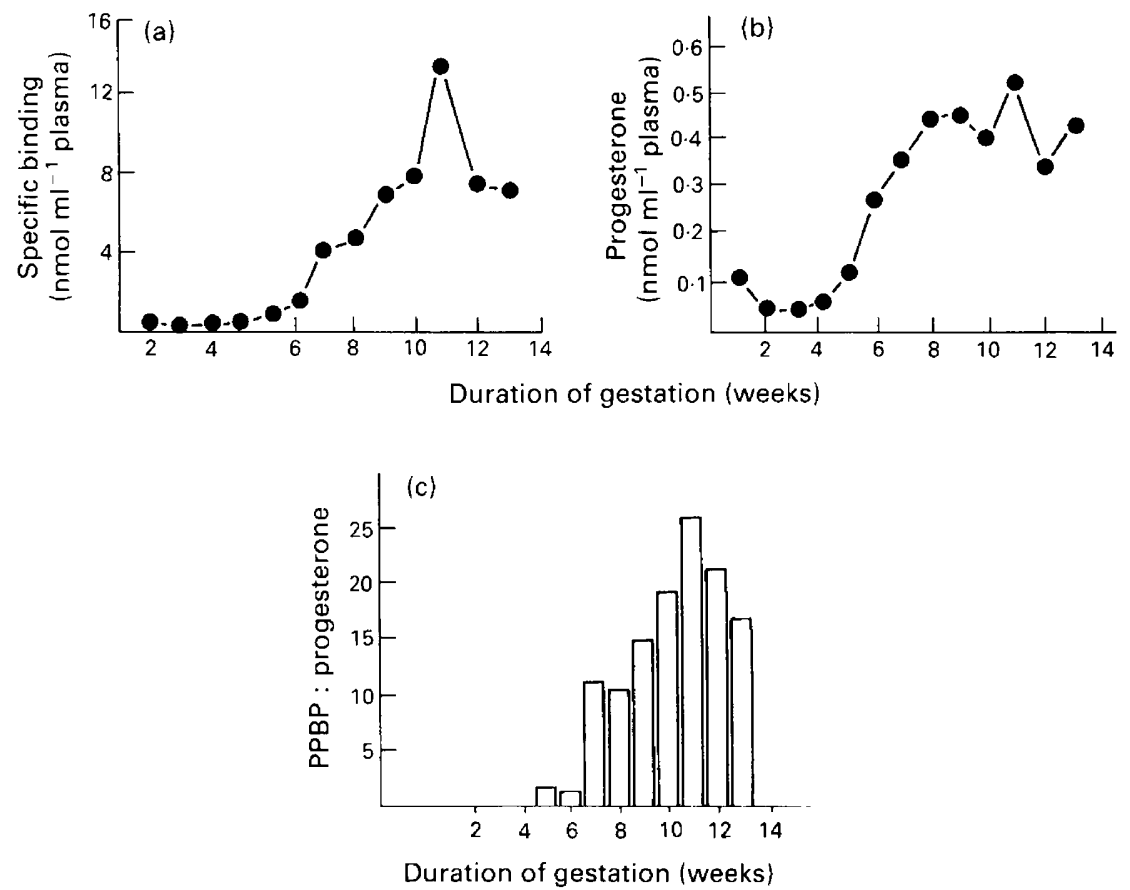

Fig. 4. Changes in concentrations of plasma progesterone-binding proteins and progesterone in pooled plasma of 11 Cape porcupines: (a) concentration of plasma progesterone-binding proteins (PPBP) in heat-treated plasma, (b) total plasma progesterone concentrations and (c) ratio of molar concentrations of PPBP and progesterone; $<0.1 \mathrm{mg}$ protein $\mathrm{ml}^{-1}$ plasma was used in the binding assays.

glycosylation. Since proteins with a smaller hydrodynamic radius than carbohydrates (Squire, 1964) were used to calibrate the Sephacryl S-200 column, the high molecular mass for PBG may be an overestimate depending on its glycoconjugate content.

The association constant $\left(K_{\mathrm{a}}\right)$ of $5 \times 10^{10} \mathrm{~mol}^{-1} 1$ for heated plasma of both day 35 and day 68 of pregnancy (Fig. 3a and b) is in agreement with the value reported by van Aarde \& Potgieter (1986), but these values are higher than those recorded for guinea-pigs (Lea, 1973; Cheng et al. 1976; Westphal et al., 1977), casiragua, cuis, degu and plains viscacha (see Heap et al., 1981). The significance of this difference between Old and New World hystricomorph rodents warrants further investigation.

The concentrations of PPBP in heated plasma of pregnant Cape porcupines increased from $67 \cdot 8$ (2.3 pmol mg ${ }^{-1}$ protein) to $2793 \mathrm{pmol} \mathrm{ml}^{-1}$ plasma (128 pmol $\mathrm{mg}^{-1}$ protein) from day 35 to 68 of pregnancy (Fig. 3a, b). Van Aarde \& Potgieter (1986) reported lower concentrations (0.322 pmol $\mathrm{mg}$ ' protein) for PPBP in native porcupine plasma. This may have been due to assays that were conducted under conditions where PPBP were not saturated with ligand as well as the binding properties of the different ligands. The protein and ligand concentrations which they used were nearly 20 times higher and four times lower, respectively, than those used in the present study.

Considerable differences in the temporal pattern of PPBP concentration exist among various species of hystricomorph rodents. During pregnancy, PPBP increased to reach maximum concentrations between days 20 and 25 and day 50 and term in guinea-pigs $\left(8 \mathrm{nmol} \mathrm{ml}^{-1}\right.$ plasma), immediately before parturition in casiragua $\left(7 \mathrm{nmol} \mathrm{m}^{-1}\right.$ plasma; day 64$)$, and in mid-gestation in cuis ( $10 \mathrm{nmol} \mathrm{ml^{-1 }}$ plasma; day 27$)$, degu ( $3 \mathrm{nmol} \mathrm{ml}^{-1}$ plasma; day 45$)$ and viscacha $\left(4 \mathrm{nmol} \mathrm{ml}^{-1}\right.$ plasma; day 75) (Heap et al., 1981). The PPBP concentrations in porcupines remained low for the 
first five weeks of pregnancy $\left(<0.01 \mathrm{nmol} \mathrm{ml}{ }^{-1}\right.$ plasma), increasing thereafter to reach a peak value at week 11 of pregnancy $(13.77 \mathrm{nmol} / \mathrm{ml}$ plasma $)$.

The molar ratio of PPBP to progesterone in the present study remained below unity for the first five weeks of pregnancy, increasing to a peak value of 25 at week 11 of pregnancy. Heap et al. (1981) found the ratio of plasma concentrations of PPBP to progesterone to exceed unity throughout pregnancy in all species studied. In guinea-pig and casiragua the ratio was similar throughout gestation (13.9 and 14.7). In cuis it increased progressively during pregnancy to a maximum value immediately before term (41.5; day 52). In degu the highest values were attained at mid-gestation, with a mean value throughout gestation of $54 \cdot 2$. In viscacha the results were more variable, ranging from 0.52 to 56 during pregnancy (Heap et al., 1981). In this respect there is apparently no obvious difference between Old and New World hystricomorph species.

The high molar ratio of PPBP to progesterone from the fifth week of pregnancy (Fig. $4 \mathrm{c}$ ) implies that only a small fraction of the total progesterone concentration would be free. This is supported by observations that approximately $2 \%$ of the total progesterone concentration is present in the free form (van Wyk, 1991) and would be in agreement with the presumed function of PPBP (Illingworth et al., 1970; Heap \& Illingworth, 1974). Since CBG also occurs in the plasma of pregnant Cape porcupines it appears that PPBP in Old and New World hystricomorph rodents are very similar in composition.

We thank the Foundation for Research Development for providing financial support.

\section{References}

Burton, R.M., Harding, G.B., Rust, N. \& Westphal, U. (1971) Steroid-protein interactions. XXIII. Nonidentity of cortisol-binding globulin and progesteronebinding globulin in guinea pig serum. Steroids 17, I-16.

Cheng, S.L., Stroupe, S.D. \& Westphal, U. (1976) Steroid protein interactions. Purification of progesteronebinding globulin by affinity chromatography. Federation of European Biochemical Societies Letters 64, $380-384$.

Daughaday, W.H., Alder, R.E., Mariz, I.K. \& Raskinski, D.C. (1962) Mesurements of the binding capacity of corticosteroid-binding globulin in human plasma. Journal of Clinical Endocrinology and Metabolism 22, $704-710$.

Heap, R.B. (1969) The binding of plasma progesterone in pregnancy. Journal of Reproduction and Fertility 18, $546-548$.

Heap, R.B. \& Illingworth, D.V. (1974) The maintenance of gestation in the guinea-pig and other hystricomorph rodents: changes in the dynamics of progesterone metabolism and the occurrence of progesteronebinding globulin (PBG). Symposium of the Zoological Society of London 34, 385-415.

Heap, R.B., Ackland, N. \& Weir, B.J. (1981) Progesteronebinding proteins in plasma of guinea-pigs and other hystricomorph rodents. Journal of Reproduction and Fertility 63, 477-489.

Huggett, A. St G. \& Widdas, W. F. (1951) The relationship between mammalian foetal weight and conception age. Journal of Physiology, London 114, 306-317.

Illingworth, D.V., Heap, R.B. \& Perry, J.S. (1970) Changes in the metabolic clearance rate of progesterone in the guinea-pig. Journal of Endocrinology 48, $409-417$.
Illingworth, D.V., Ackland, N., Heap, R.B. \& Weir, B.J. (1973) Progesterone-binding proteins: occurrence, capacity and binding affinity in hystricomorph rodents. Journal of Endocrinology 58, ii.

Lea, O.A. (1973) Isolation and characterisation of a progesterone- and testosterone-binding globulin from pregnant guinea pig serum. Biochimica et Biophysica Acta 317, 351-363.

Milgrom, E., Atger, M. \& Baulieu, E-E. (1970) Progesterone in uterus and plasma. IV-Progesterone receptor(s) in guinea pig uterus cytosol. Steroids 16, $741-754$.

Milgrom, E., Luu Thi, M. \& Baulieu, E-E. (1973a) Control mechanism of steroid hormone receptors in the reproductive tract. Acta Endocrinologica Supplementum 180, 380-403.

Milgrom, E., Allouch, P., Atger, M. \& Baulieu, E-E. (1973b) Progesterone-binding plasma protein of pregnant guinea pig. Journal of Biological Chemistry 248, 1106-1]14.

Philibert, D. \& Raynaud, J.P. (1974) Progesteronebinding in immature rabbit and guinea-pig uterus. Endocrinology 94, 627-632.

Philibert, D., Ojasoo, T. \& Raynaud, J.P. (1977) Properties of the cytoplasmic progestin-binding protein in the rabbit uterus. Endocrinology 101, 1850-1860.

Reinard, T. \& Jacobsen, H-J. (1989) An inexpensive small volume equilibrium dialysis system for proteinligand binding assays. Analytical Biochemistry 176, $157-160$.

Scatchard, G. (1949) The attractions of proteins for small molecules and ions. Annals of the New' York Academy of Science 51, 660-672.

Siiteri, P.K., Murai, J.T., Hammond, G.L., Nisker, J.A., Raymoure, W.J. \& Kuhn, R.W. (1982) The serum 
transport of steroid hormones. Recent Progress in Hormone Research 38, 457-503.

Stroupe, S.D. \& Westphal, U. (1975) Conformational changes in the progesterone binding globulin-progesterone complex. Biochemistry 14, 3296-3300.

Squire, P.G. (1964) A relationship between the molecular weights of macromolecules and their elution volumes based on a model for Sephadex gel filtration. Archives of Biochemistry and Biophysics 107, 471-478.

Tam, W.H. (1974) The synthesis of progesterone in some hystricomorph rodents. Symposium of the Zoological Society of London 34, 363-384.

Van Aarde, R.J. (1987) Pre- and postnatal growth of the Cape porcupine Hystrix africaeaustralis. Journal of Zoology, London 211, 25-33.

Van Aarde, R.J. \& Potgieter, H.C. (1986) Circulating progesterone, progesterone-binding proteins and oestradiol- $17 \beta$ concentrations in the pregnant Cape porcupine, Hystrix africaeaustralis. Journal of Reproduction and Fertility. 76, 561-567.

Van Aarde, R.J. \& Van Wyk, V. (1991) Reproductive inhibition in the Cape Porcupine, Hystrix africaeaustralis. Journal of Reproduction and Fertility 92, 13-19.

Van Wyk, V. (1991) Plasma progesterone-binding proteins in the Cape porcupine, Hystrix africaeaustralis. MSc thesis, University of Pretoria, Pretoria.

Westphal, U., Stroupe, S.D. \& Cheng, S-L. (1977) Progesterone binding to serum proteins. Annals of the New' York Academy of Science 286, 10-27.

Received 15 July 1991 